\title{
O FILANTROCAPITALISMO NA POLÍTICA EDUCACIONAL BRASILEIRA: EDUCAÇÃO INTEGRAL E RELAÇÃO PÚBLICO-PRIVADO
}

\author{
Jaqueline da Conceição Camargo*, Débora Cristina Jeffrey.
}

\section{Resumo}

A trajetória da educação integral no Brasil não se trata de algo novo, além de ser cenário de continuidades e remodelações. Os últimos vinte anos tiveram destaque na efetivação dessa política em todo o território nacional, com foco a partir de 2007 tendo o Programa Mais Educação como medida indutora para esta modalidade de ensino. No processo, chama a atenção o considerável quantitativo de fundações - ligadas à iniciativa privada - atuantes junto aos estados brasileiros, principalmente na região Nordeste, na implantação da política. A partir disso, este artigo tem como objetivo apresentar os desdobramentos da pesquisa Constituição das redes através da política de educação integral no Brasil (UNICAMP /UNIR/ UFOPA) PROCAD/CAPES. A partir do Programa Mais Educação, a discussão avança para o aprofundamento na análise da relação histórica entre os agentes público e privado no cenário educacional brasileiro, com manifestação do filantrocapitalismo através da governança filantrópica; legitimada em território nacional pelos Arranjos de desenvolvimento da educação.

\section{Palavras-chave:}

Educação Integral, Filantrocapitalismo, Política Educacional.

\section{Introdução}

A Educação Integral no Brasil é tema de continuidades e remodelações em torno de sua implantação, sendo difundida enquanto política pública de educação nacional na LDBEN no 9.394/1996 (BRASIL, 1996) e consolidada com o lançamento do Plano de Desenvolvimento da Educação - PDE em 2007, tendo no Programa Mais Educação uma medida de indução para a melhoria da educação brasileira que articula a ampliação da jornada escolar com a plena formação dos estudantes. O panorama apresentado possibilitou a pesquisa sobre 0 histórico de implementação da educação integral no Brasil através da análise quantitativa e qualitativa de informações coletadas em relação à implantação da modalidade de ensino em secretarias estaduais de educação com o Programa Mais Educação. O estudo voltou-se para a investigação acerca da inserção da iniciativa privada na política pública de educação através da participação das Organizações da Sociedade Civil de Interesse Público (OSCIPS) vinculadas a grandes grupos empresariais e financeiros no cenário educacional brasileiro, com incentivo à Educação Integral, estabelecendo um desenho da governança filantrópica no Brasil.

\section{Resultados e Discussão}

A partir da análise realizada no último período observouse a atuação de dezesseis OSCIPS em todas as cinco regiões administrativas do Brasil, com destaque para o Nordeste e o Sudeste, respectivamente. Outro ponto de destaque é o desenvolvimento de projetos e ações voltadas no discurso de promoção da qualidade da educação, principalmente à população em situação de vulnerabilidade social. A partir dessa perspectiva, questiona-se se o interesse dessas fundações nos estados brasileiros trata-se de um compromisso social ou interesse corporativo, tendo em vista que os membros dessas organizações também participam de conselhos e departamentos de gestão de grandes grupos empresariais e financeiros, nacionais e internacionais? Uma reflexão que considera a tomada de decisão pelo Estado neoliberal na lógica de mercado/consumo, pois, na medida em que as fundações colocam em prática suas ações filantrópicas, não deixam de lucrar com a destinação de verbas públicas educacionais, caracterizando o filantrocapitalismo (OLMEDO, 2013. BALL, 2014. BISHOP. GREEN, 2009).

\section{Conclusões}

As discussões em torno da implementação da educação integral na política educacional brasileira, ampliam a reflexão e diversificam as pesquisas em torno do campo da educação pública no Brasil. A relação entre público e privado através da efetivação de políticas públicas pela lógica de mercado, configura a governança filantrópica (Olmedo, 2013) em que o estado transfere a responsabilidade de suas ações para a iniciativa privada. Estabelecer um desenho da governança filantrópica no Brasil através da crescente atuação das fundações permite refletir sobre o fortalecimento do filantrocapitalismo em diversas economias pelo mundo, entre elas, a brasileira, pois a dinâmica de atuação dessas fundações trata-se do interesse corporativo revestido de compromisso social uma vez que promovem um discurso de contribuição para a qualidade da educação ao mesmo tempo em que lucro com os recursos governamentais.

\section{Agradecimentos} GEPALE - FE/Unicamp; CAPES; CONEPPA.

BALL, S. J. Educação global S.A.: novas redes políticas e o imaginário neoliberal. Ponta Grossa: UEPG, 2014

BISHOP, M. GREEN, M. Philanthrocapitalism: How giving can save the world. Bloomsbury press: New York, 2009.

BRASIL. Lei $\mathbf{n}^{\circ}$ 9.394, de 20 de dezembro de 1996. Estabelece as diretrizes e bases da educação nacional.

OLMEDO, A. Heterarquias e "governança filantrópica" global na Inglaterra: Implicações e controvérsias para o controle social das políticas sociais. Educação e Políticas em Debate, Uberlândia, v. 2, n. 2, p.470-498, jul/dez 2013. 